\title{
TEACHING FL PRONUNCIATION IN THE GLOBALIZATION ERA. DOES IT MAKE SENSE?
}

\author{
MAGDALENA POSPIESZYŃSKA-WOJTKOWIAK
}

The place of pronunciation teaching is particularly important in FL pedagogy and is gaining more and more interest among phonetics instructors which can be confirmed by the papers presented at phonetic conferences in Poland (see Dydaktyka Fonetyki Języka Obcego - Zeszyty Naukowe PWSZ w Ptocku 2002 and 2003 and Zeszyty Naukowe PWSZ w Koninie 2003 and 2004). Pronunciation teaching can influence the quality of a spoken language but can also help us understand certain linguistic phenomena concerning speech acts, vocal tract or speech production, transmission and perception. A person who is trained to be an English teacher should not only be a good language user but also be able to comprehend, interpret and explain particular phonological rules and principles.

In his book on issues in English language teaching and learning, Widdowson (2003) presents two quotations which can be interpreted as representing two opposing positions on English language change. The first quotation is taken from Yeats's The Second Coming:

Things fall apart: the centre cannot hold

Mere anarchy is loosed upon the world.

The second quotation is taken from Tennyson's Idylls of the King:

The old order changeth, yielding place to new

And God fulfils himself in many ways,

Lest one good custom should corrupt the world. 
Let us try to understand Widdowson's interpretations of the quotations mentioned above. In the case of Yeats', Widdowson (2003: 58) says:

the centre can be taken as the Inner Circle and the assumption is that if it cannot hold the language in place, linguistic anarchy will be loosed upon the English speaking world.

In the case of the other quotation, Widdowson (ibid).) claims (cf. Howatt and Widdowson 2004) that:

whether you attribute it to some kind of divine intervention or not, the old established order of Inner Circle English changes and yields place to new varieties of English.

Although the current trend for language intelligibility and global understanding in EFL may undermine the role of pronunciation teaching/learning, the majority of both teachers and students find it equally important as teaching/learning grammar or lexis. (The acronym ELF, English as Lingua Franca ${ }^{1}$, in reversing the $\mathrm{F}$ and L of EFL, may be taken as a symbol of the conceptual and practical contrasts between EFL and ELF). Some may, however, claim that there is no reason to teach phonetics at all age levels due to the fact that the critical period for pronunciation is believed to be earliest of all ( $\sim 6$ years of age). However, even though not all learners will achieve native-like pronunciation, research studies have shown that highly motivated adult learners with sufficient training can attain it (e.g. Pennington 1994, Florez-Cunningham 1998).

English has become a means of global communication, so maybe being intelligible should be the aim of phonetics teaching in the globalization era? Yet, there are no criteria for universal intelligibility. We may only assume that intelligibility means intelligibility to a native speaker. Indeed, Smith (1987) concludes that both in ESL and EFL English has been perceived as a sole property of native speakers and the emphasis of FL learning has been on speech acts between a native speaker and a non-native speaker only. Thus, it implies that nonnative speakers of English should work towards a native-like communicative competence. In a similar vein Sridhar (1985: 101) comments:

It was just assumed that English is learned to interact with native speakers of the language, and to imbibe Anglo-American culture, so the native standards were the norm, the native customs and concerns provided the content of teaching materials.

However, the majority of transactions in English take place between nonnative language users, hence the assumption that non-native speakers interact

\footnotetext{
${ }^{1}$ A lingua franca in its original sense was a variety spoken along the South-Eastern coast of the Mediterranean between approximately the 15-th and 19-th century. It was probably based on some Italian dialects in its earliest history including elements from Spanish, French, Portuguese, Arabic, Turkish, Greek and Persian. See Knapp and Meierkord (2002) for further details.
} 
primarily with native speakers is no longer valid (Taylor 1991). Research shows that there are now circa 750 million non-native speakers of English and about 375 million native speakers and 375 million speakers of English as a second language (Graddol 1997, cf. Kachru 1986, Melchers and Shaw 2003). Thus, it is possible that many interactions in English take place among non-native speakers without any native speakers involved in the transactions. If it is so, maybe the goal for pronunciation teaching should be changed or individually adopted only for particular learners? (cf. Davies et al. 2003, Jenkins 2000 and forthcoming, Lowenberg 2002, Matsuda 2002 and 2003, McKay 2002, Seidlhofer 2001, 2004 and forthcoming) As Leather puts it light-heartedly: "only spies need truly native-like accents" (1983: 198), though he adds "(...) and only teachers of L2 need to be near-native" (ibid.), which seems to be quite conflicting with the goal for comfortable intelligibility and social acceptance. Ironically, some intelligibility studies (Smith and Rafiqzad 1985) showed that native speakers' pronunciation is not the most intelligible, e.g. American native speakers were the least intelligible even to their fellow countrymen.

Taking into account the goal of intelligibility, there are a few questions arising that teachers have to consider. Firstly, what English to teach and then why teach phonetics at all? Choosing an appropriate language model allows us to set certain standards and to aim at attaining the targets. Nevertheless, Taylor (1990) thinks that one of the major weaknesses of the phonetics-dominated model is that it always concentrates on one variety of native speaker English. We may not know whether the chosen model is widely acceptable by all learners, whether our model will become their objective too, and what they really think about attaining this particular variety (cf. Sobkowiak 2003, Szpyra-Kozłowska 2004). Certainly, both teachers and learners need some kind of English standard that can be referred to as a basis for defining the models and objectives. Trim (1962: 30) says:

a uniform standard practice is, in teaching as in any other practical activity, a source of great strength, since it affords researchers, teachers and students alike a coherent cumulative body which each can explore and extend without encountering inconsistencies and contradictions.

It is the usefulness of pronunciation teaching which has been debated and the role of pronunciation teaching in language curricula that has been widely discussed in recent days. There are some contradictory research results concerning the effectiveness of phonetics teaching. On the one hand, the studies carried out by Suter and Purcel prove that there is no relationship between teaching practical phonetics in the classroom and the attained proficiency in students' pronunciation (Purcel and Suter 1980, Suter 1976). On the other hand, other researchers (Derwing et al. 1998, MacDonald et al. 1994, Pennington 1989) believe that 
experienced teachers using appropriate materials and following a communicative language programme can improve students' pronunciation.

Although Krakowian (2000: 120) claims that "fortunately (...) very few people want to sound exactly as native speakers so teachers need not to spend too much time teaching correct pronunciation", Lyster (2001) found out that it is phonological errors that teachers mostly correct in the classroom - not grammatical or vocabulary ones. Krakowian (ibid.) claims that such phonological features as, e.g., accent should not worry the learners because it is enough "if they can make themselves perfectly understandable in the target language" (Krakowian 2000: 120). What is even more, he suggests that the students "should not be too ambitious" (ibid.) and would rather go on to learn other aspects of the FL instead of "wasting time on trying to bring their pronunciation up to the native speaker level" (ibid.). Surprisingly enough, Lyster (2001) having analyzed 1100 minutes of learners' interaction in French immersion programmes established the correction rate for phonological errors at as much as 70 per cent. Another study conducted by Pawlak (2002) provided data on the correction rate for pronunciation errors in classroom situations, and he found the correction rate to be at $26 \%$ and only grammatical errors outnumbered the figure.

Morley (1999) enumerates four main goals of pronunciation teaching, which the present author is going to comment on below:

- functional intelligibility;

- functional communicability;

- increased self-confidence;

- speech monitoring abilities.

Intelligible pronunciation is an essential component of communicative competence and if non-natives' pronunciation falls below a certain threshold level, they will not be able to communicate orally no matter how good their control of English grammar and vocabulary might be (Celce-Murcia 1987, Morley 1991). Thus, learners should understand that phonetics is important if they want to sound socially acceptable and realize that improper pronunciation may hinder communication, making them not even intelligibly communicative. Besides, good pronunciation boosts the learners' confidence in their ability to understand and be understood, which may contribute to their greater willingness to use the target language. Thus, pronunciation instruction aims at assuring the teacher of his/her students' abilities to focus on their speech and the speech of others, and will allow them to spot the discrepancies between their speech and the speech of more proficient FL users (Pawlak 2004). Furthermore, among the qualifications that a language teacher should possess we would inevitably enumerate good linguistic competence, particularly good phonological competence in the L2. Arabski (1996) points out that in phonological competence the teacher's abilities should be close to these of a native speaker. Moreover, teachers ought to be pre- 
dominantly sensitive to the learners' pronunciation errors and be ready to diagnose and correct them immediately in order to prevent fossilization.

The present author is not going to platitudinize about how important explicit FL pronunciation teaching is or ask whether we should teach it or not. For all sceptics or the proponents of Lingua Franca Core it is suggested that they read the articles by e.g. Fraser (1999), Sobkowiak (2003), Waniek-Klimczak (1997), Wysocka (2003) or Komorowska-Janowska (2006) - to name only a few. Unfortunately, pronunciation is the aspect of EFL that still receives little attention. One of the reasons for that, as Fraser (ibid.) points out, may not be 'unwillingness to teach' but lack of knowledge how effectively to do that to 'help learners best'. Fraser also makes the point that although the knowledge of FL descriptive phonetics and phonology is useful for the ESL/EFL learners in general, it is not 'needed for pronunciation classes' (sic.). She then concludes that pronunciation instructors should possess the knowledge about speech perceptions and EFL phonology system. Zybert (1997), conversely, thinks that learners should receive sufficient descriptive instruction to become aware of the allophonic distinctions, contrastive differences or potential similarities between their mother tongue and L2. But, first of all, Fraser (1999: 7-8) notes that pronunciation teachers ought to (cf. Strange 1995):

have insight into the kinds of problems learners face in pronouncing English, and tools to provide for their needs at different stages.

Pronunciation is a skill to be acquired. It cannot be perceived only as a part of declarative knowledge (knowing - what) but primarily as a part of procedural knowledge (knowing - how), which is acquired gradually and must be exercised a lot. Fraser (1999) points to the link between learning pronunciation and practising sport or playing a musical instrument, where the same amount of motivation, time and effort must be invested to achieve success. By the same token, Underhill (1995) compares pronunciation work to coaching in sport, athletics or dance. For all of the reasons, one of the goals of pronunciation teaching/learning should be making it both a physical as well as a cognitive activity. Learners must try to stop regarding pronunciation work as an abstract notion and focus on the muscles that produce sounds, rhythm and intonation (cf. Higgins et al. 1995). It is very important to "get pronunciation work out of the head and into the body" (Underhill 1995: 1).

\section{References}

Arabski, J. 1996. Przyswajanie języka obcego i pamięć werbalna. Katowice: “Śląsk”.

Bickley, V. (ed.). 1990. Language use, language teaching and the curriculum. Hong Kong: Education Department, Institute of Language in Education. 
Celce-Murcia, M. 1987. “Teaching pronunciation as communication”. In: Morley, J. (ed.). 5-12.

Davies, A., Hamp-Lyons, L. and C. Kemp. 2003. "Whose norms? International proficiency tests in English". World Englishes 22 (4). 572-584.

Derwing, T.M., Munro, M.J. and G. Wiebe, 1998. "Evidence in favour of a broad framework for pronunciation instruction". Language Learning 48 (3). 393-410.

Dydaktyka Fonetyki Języka Obcego. Zeszyty Naukowe Państwowej Wyższej Szkoty Zawodowej w Płocku. Neofilologia, Tom II. 2002. Płock: Wydawnictwo Naukowe PWSZ w Płocku.

Dydaktyka Fonetyki Języka Obcego. Zeszyty Naukowe Państwowej Wyższej Szkoty Zawodowej w Płocku. Neofilologia, Tom V. 2003. Płock: Wydawnictwo Naukowe PWSZ w Płocku.

Ellis, R. 2001. Form-focused instruction and second language learning. Oxford: Blackwell.

Florez-Cunningham, M. 1998. Improving adult ESL learners' pronunciation skills. Washington DC: ERIC Digest - an Internet Magazine. Internet Site: http://www.ericfacility.net/ericdig ests/ed427553.html

Fraser, H. 1999. "ESL pronunciation teaching: could it be more effective?". Australian Language Matters 7 (4). 7-8.

Higgins, M., Higgins, M. and Y. Shima. 1995. "Basic training in pronunciation and phonics: a sound approach". The Language Teacher 19 (4). 4-8, 16.

Howatt, A. and H.G. Widdowson. 2004. (2-nd ed.). A history of English language teaching. Oxford: Oxford University Press.

Jenkins, J. 2000. The phonology of English as an international language. Oxford: Oxford University Press.

Kachru, B.B. 1986. The alchemy of English: the spread, functions and models of non-native Englishes. Oxford: Pergamon Press.

Knapp, P. and C. Meierkord (eds.). 2002. Lingua franca communication. Frankfurt am Main: Peter Lang.

Komorowska-Janowska, H. 2006. "Teaching English as a lingua franca”. In: Zybert, J. (ed.). 111-123.

Krakowian. B. 2000. Selected principles in teaching English as a foreign language to children and adults. Łódź: Wydawnictwo Uniwersytetu Łódzkiego.

Leather, J. 1983. "Second language pronunciation learning and teaching". Language Teaching 16. 198-219.

Lowenberg, P. 2002. "Assessing English proficiency in the Expanding Circle". World Englishes 12 (3). 431-435.

Lyster, R. 2001. "Negotiation of form, recasts and explicit correction in relation to error types and learner repair in immersion classrooms". In: Ellis, R. (ed.). 265-301.

MacDonald, D., Yule, G. and M. Powers. 1994. "Attempts to improve English L2 pronunciation: the variable effects of different types of instruction". Language Learning 44 (1). 75-100.

Matsuda, A. 2002. "International understanding' through teaching world Englishes". World Englishes 21 (3). 436-440.

Matsuda, A. 2003. "Incorporating world Englishes in teaching English as an international language”. TESOL Quarterly 37 (4). 719-729.

Melchers, G. and P. Shaw. 2003. World Englishes. London: Arnold.

McKay, S. 2002. Teaching English as an international language. Oxford: Oxford University Press.

Morley, J. 1991. "The pronunciation component in teaching English to speakers of other languages". TESOL Quarterly 25 (1). 51-74.

Morley, J. 1999. "New developments in speech/pronunciation instruction". As We Speak... (Newsletter of the TESOL Speech/Pronunciation Interest Section) 2. 1-5.

Morley, J. (ed.). 1987. Current perspectives on pronunciation. Washington DC: TESOL. 
Morley, J. (ed.). 1994. Pronunciation pedagogy and theory. New views, new directions. Alexandria, UA: Teachers of English to Speakers of Other Languages.

Pawlak, M. 2002. "Error correction practices of Polish and American teachers". Studia Anglica Posnaniensia 37. 293-316.

Pawlak, M. 2004. "The role of error correction in teaching pronunciation". In: Zeszyty Naukowe Państwowej Wyższej Szkoty Zawodowej w Koninie1/2004 (4). Zeszyt Naukowy Instytutu Neofilologii (3). Materiaty z konferencji "Dydaktyka fonetyki języka obcego w Polsce”; Mikorzyn k. Konina, 10-12 maja 2004. Konin: Wydawnictwo PWSZ w Koninie. 66-74.

Pennington, M. 1989. “Teaching pronunciation from the top down”. RELC Journal 20 (1). 21-38.

Pennington, M. 1994. "Recent research in L2 phonology. Implications for practice". In: Morley, J. (ed.). 92-108.

Purcel, E. and R. Suter. 1980. "Predictors of pronunciation accuracy: a reexamination." Language Learning 30 (2). 271-287.

Seidlehofer, B. 2001. "Closing a conceptual gap: the case for a description of English as a lingua franca". International Journal of Applied Linguistics 11 (2). 133-158.

Seidlehofer, B. 2004. "Research perspectives on teaching English as lingua franca". Annual Review of Applied Linguistics 24. 209-239.

Smith, L.E. (ed.). 1987. Discourse across cultures. strategies in world Englishes. Englewood Cliffs, NJ: Prentice Hall.

Smith, L.E. and K. Rafiqzad. 1985. "English for cross-cultural communication: the question of intelligibility. TESOL Quarterly 13. 371-380.

Sobkowiak, W. 2003. "Dlaczego nie LFC”. In: Dydaktyka Fonetyki Języka Obcego. Zeszyty Naukowe Państwowej Wyższej Szkoły Zawodowej w Płocku. Neofilologia, Tom V. Płock: Wydawnictwo Naukowe PWSZ w Płocku. 114-124.

Sridhar, K.K. 1985. "Review of Smith, L.E. (ed.). 1985. 'Readings in English as an International Language'”. RELC Journal 16. 101-106.

Strange, W. 1995. Speech perception and linguistic experience: issues in cross-language research. Baltimore: York Press.

Suter, R. 1976. "Predictors of pronunciation accuracy in second language learning". Language Learning 26. 233-253.

Szpyra-Kozłowska, J. 2004. „Jaki model wymowy angielskiej? - dyskusji ciąg dalszy”. In: Zeszyty Naukowe Państwowej Wyższej Szkoty Zawodowej w Koninie1/2004 (4). Zeszyt Naukowy Instytutu Neofilologii (3). Materiaty z konferencji „Dydaktyka fonetyki języka obcego Polsce”; Mikorzyn k. Konina, 10-12 maja 2004. Konin: Wydawnictwo PWSZ w Koninie. 116-123.

Taylor, D.S. 1990. "The place of phonetics, phonology and transcription in language teaching”. In: Bickley, V. (ed.). 384-392.

Taylor, D.S. 1991. "Who speaks English to whom? The question of teaching English pronunciation for global communication". System 19 (4). 425-435.

Trim, J.L. 1962. "English standard pronunciation”. English Language Teaching 16. 28-37.

Underhill, A. 1995. "Making pronunciation work for your learners". Internet Site: http://langue. hyper.chubu.ac.jp/jalt/pub/tlt/96/sept/pron.html

Waniek-Klimczak, E. 1997. "Context for teaching English phonetics and phonology at Polish universities and colleges: a survey”. In: Waniek-Klimczak, E. (ed.). 5-17.

Waniek-Klimczak, E. (ed.) 1997. Teaching English phonetics and phonology II: accents. Łódź: Wydawnictwo Uniwersytetu Łódzkiego.

Widdowson, H.G. 2003. Defining issues in English language teaching. Oxford: Oxford University Press. 
Wysocka, H. 2003. "Czy/Jak uczyć fonetyki języka obcego”. In: Zeszyty Naukowe Państwowej Wyższej Szkoty Zawodowej w Koninie, Tom 1/2003 (2). Zeszyt Naukowy Instytutu Neofilologii (2). Konin: Wydawnictwo PWSZ w Koninie. 159-184.

Zeszyty Naukowe Państwowej Wyższej Szkoły Zawodowej w Koninie, Tom 1/2003 (2). Zeszyt Naukowy Instytutu Neofilologii (2). 2003. Konin: Wydawnictwo PWSZ w Koninie.

Zeszyty Naukowe Państwowej Wyższej Szkoty Zawodowej w Koninie1/2004 (4). Zeszyt Naukowy Instytutu Neofilologii (3). Materiaty z konferencji ,Dydaktyka fonetyki języka obcego w Polsce”; Mikorzyn k. Konina, 10-12 maja 2004. Konin: Wydawnictwo PWSZ w Koninie.

Zybert, J. 1997. "Acquisition of L2 phonetic features". Papers and Studies in Contrastive Linguistics 32. 103-117.

Zybert, J. (ed.). 2006. Issues in foreign language learning and teaching. Warszawa: Wydawnictwa Uniwersytetu Warszawskiego. 